Література

1. Кривда ГФ, Дем’янчук АП, Котельникова ВО, Старовойтова РО, Кривда РГ. Судово-медичне дослідження речових доказів: навч.-метод. посіб. Херсон: Наддніпряночка; 2014. 460 с.

2. Економічне районування України: принципи та постановка проблеми [інтернет]. Економічна наука; 2015 [оновлено 2015 Тра 14; цитовано 2018 Фев 15]. Доступно: https://alter-idea.info/p/663.html

3. Старовойтова РА. Этническая геногеография Украинской ССР: монографія. Київ: Наукова думка; 1979. $143 \mathrm{c}$.

\title{
References:
}

1. Kryvda HF, Demianchuk AP, Kotelnykova VO, Starovoitova RO, Kryvda RH. Sudovo-medychne doslidzhennia rechovykh dokaziv: navch.-metod. posib. [Forensic examination of material evidence: teaching method. manual]. Kherson: Naddniprianochka, 2014. 460 s. (in Ukrainian)

2. Ekonomichne raionuvannia Ukrainy: pryntsypy ta postanovka problem [Economic zoning of Ukraine: principles and problem statement] [internet]. Ekonomichna nauka; 2015 [onovleno 2015 Tra 14; tsytovano 2018 Fev 15 ]. Dostupno: https://alter-idea.info/p/663.html (in Ukrainian)

3. Starovoytova RA. Etnicheskaya genogeografiya Ukrainskoy SSR: monografiya [Ethnic genogeography of the Ukrainian SSR: monograph]. Kiev: Naukova dumka; 1979. 143 s. (in Russian)

\section{ANALYSIS OF THE DISTRIBUTION OF PHENOTYPES OF THE BLOOD GROUP SYSTEM ABO IN THE POPULATION OF UKRAINE}

Kryvda R., Kotelnykova V., Stoieva M., Bukina V., Andreieva H., Al-Taiavi Y., Shpykuliak O., Mykhailiuk N., Aleinyk S., Trykoza Y., Romantsova T., Mychailenko S., Medova I., Tymchenko I., Bronnikova L., Kaplevska S., Makoviichuk A.

Summary. The article shows new data on the prevalence of various blood group phenotypes of AB0 system in Ukraine, the dynamics of its fluctuations being analyzed over the last decade and the degree of interregional variations being established in comparison with the latest thematic research in 1979. Based on the analysis, the most common blood group in AB0 system in Ukraine is identified and the expediency of using the obtained statistical data in the practice of forensic lab experts is shown.

Key words: blood group, system $\mathrm{AB} 0$, population, prevalence.

\section{АНАЛИЗ РАСПРОСТРАНЕННОСТИ ФЕНОТИПОВ СИСТЕМЫ ГРУПП КРОВИ АВО СРЕДИ НАСЕЛЕНИЯ УКРАИНЫ}

Кривда Р. Г., Котельникова В. А., Стоева М. И., Букина В. В., Андреева Г. Н., Аль-

Тайави Я. А., Шпикуляк Е. А., Михайлюк Н. Н., Алейник С. И., Трикоза Ю. С., Романцова Т. И., Михайленко С. В., Медовая И. А., Тимченко И. В., Бронникова Л. А., Каплевская С. В., Маковийчук А. В.

Резюме. В статье приведены новые данные о распространенности различных фенотипов групп крови системы $\mathrm{AB} 0$ в Украине, проанализирована динамика ее колебаний за последнее десятилетие и степень межобластных вариаций по сравнению с последним тематическим исследованиям 1979 года. На основе анализа выделена наиболее распространенная в Украине группа крови системы АВ0 и показана целесообразность использования полученных статистических данных в практике судебных экспертов-иммунологов.

Ключевые слова: группа крови, изосерологическая система АВ0, популяция, распространенность

\section{УДК 340.6:616-076:577.21 \\ АЛГОРИТМ ПРОВЕДЕННЯ СУДОВО-МЕДИЧНӦ̈ ЕКСПЕРТИЗИ РЕЧОВИХ ДОКАЗІВ - БІОЛОГІЧНИХ ТКАНИН, ФІКСОВАНИХ У ФОРМАЛІНІ, ЗА ДОПОМОГОЮ МОЛЕКУЛЯРНО-ГЕНЕТИЧНИХ МЕТОДІВ}

СКривда Р. $\Gamma^{1}$, Ланцман I. В. ${ }^{2}$

${ }^{1}$ КУ «Одеське обласне бюро судово-медичної експертизи»

${ }^{2}$ Одеський національний медичний університет

Резюме. В роботі розглянуто питання проведення судово-медичної експертизи речових доказів - об'єктів судово-медичного гістологічного дослідження, а саме фіксованих біологічних тканин, відібраних від трупів у вигляді «волого архіву», «парафінових блоків» та фіксованих біологічних тканин біопсійного матеріалу у вигляді «парафінових блоків» та фарбованих гістологічних препаратів на предметних скельцях.

Ключові слова: ПЛР, біологічна тканина, фіксована формаліном в «парафінових блоках», депарафінізація, геномна ДНК, судово-медична експертиза. 
ВСТУП. Використання молекулярно-генетичних методів для дослідження гістологічних препаратів в судово-медичній експертній практиці з метою встановлення ДНК-профілю складає до 3,0 \% від загальної кількості досліджених біологічних об'єктів. Необхідність в дослідженні гістологічних препаратів в експертній практиці виникає у разі відсутності будь-яких придатних для ДНК-аналізу біологічних зразків від конкретної осо- би. Внаслідок чого, гістологічні препарати можуть бути єдиним збереженим та придатним об’єктом дослідження.

У 95 \% випадків судово-медичну експертизу гістологічних препаратів призначає суд відповідно до ухвал по цивільним справам з метою встановлення біологічного батьківства або встановлення родинних зв'язків у разі відсутності біологічних зразків від передбачуваного батька або передбачуваних родичів. Внаслідок чого, 75 \% біологічних об'єктів - це аутопсійний (трупний) матеріал - біологічні тканини фіксовані розчином формаліну у вигляді «волого архіву», у вигляді «парафінових блоків», а також у вигляді фарбованих гістологічних препаратів на предметних скельцях. Наступні 20 \% об’єктів - це біопсійний матеріал, відібраний від передбачуваного батька або передбачуваних родичів, якщо особа протягом життя страждала від захворювань, при яких проводяться діагностичні біопсійні заходи. Дані біологічні об’єкти повинні бути процесуально та юридично вірно оформлені, з метою їх подальшого дослідження у якості біологічних зразків від передбачуваного батька, родичів.

У 5 \% випадків судово-медичну експертизу гістологічних препаратів проводять 3 метою встановлення тотожності між гістологічним препаратом та біологічним зразком особи шляхом проведення порівняльного аналізу ДНК-профілю гістологічного препарату з ДНК-профілем зразка особи. Проводиться така експертиза у випадках, коли заявник - пацієнт лікувальної установи ставить під сумнів результати саме його гістологічного дослідження в клінічній практиці, яке проведене в процесі діагностики захворювань, особливо така ситуація виникає при онкологічних процесах, де має місце активне розмноження клітин пухлини. Даний вид досліджень зустрічається вкрай рідко, але він існує і може бути вирішений саме таким способом.

Також судово-медична експертиза 3 метою встановлення тотожності гістологічних препаратів проводиться по кримінальних справах при виникненні підозри на підміну гістологічних препаратів внаслідок суперечливих висновків судово-медичної гістологічної експертизи, наприклад, об'єктами судово-медичної експертизи можуть бути препарати шкіри при механічній асфіксії, препарати м'яких тканин при ушкодженні тупими, гострими пред- метами та інше.

На базі відділення судово-медичних молекулярно-генетичних експертиз Одеського обласного бюро судово-медичної експертизи та за участю співробітників кафедри судової медицини Одеського національного медичного університету 32012 року була розпочата наукова робота, присвячена використанню молекулярно- генетичних методів для дослідження гістологічних препаратів в судовомедичній експертній практиці з метою встановлення біологічного батьківства, ідентифікації особи та встановлення тотожності.

На сьогоднішній день основні результати цієї роботи опубліковані у вигляді трьох статей у фахових виданнях та декількох тез доповідей на науково-практичних міжнародних конференціях. Також дослідження гістологічних препаратів на сьогодні є етапом науково-дослідної роботи кафедри судової медицини ОНМедУ (УДК 340.6:616- 076:577.21 № держреєстрації 0115U006636) за темою: «Оптимізація проведення судово-медичної експертизи різних біологічних об'єктів з використанням ДНК-аналізу в експертних установах МОЗ України» [1, 2, 3].

При дослідженні гістологічних препаратів у вигляді «вологого архіву» існує проблема негативного впливу фіксуючої рідини на структуру молекули ДНК. Відповідно до літературних джерел такі фіксатори, як $10 \%$ роз- чин формаліну та $4 \%$ розчин формальдегіду є найбільш вживаними гістологічними фіксаторами, при цьому вони по різному, частіше негативно впливають на ДНК. Фіксація біологічних тканин в розчині формальдегіду негатив- но впливає на структуру ДНК утворюються шиффові основи, що призводить до зменшення кількості виділеної ДНК. Під дією розчину формаліну відбувається поперечне зв'язуванні з гістонами і реакція з нуклеотидами, яка виражається в зміні нуклеотидних послідовностей. Необхідно враховувати фактори, які впливають на фіксацію: використання буферу, дія фіксатору, пенентрація в тканини, об'єм, температура, концентрація фіксатору, термін фіксації і проміжок від моменту відібрання біологічного матеріалу до його фіксації.

При дослідженні гістологічних препаратів у вигляді «парафінових блоків» виникає проблема вибору спо- собу депарафінізації і методу виділення ДНК. Вибір способу депарафінізації і метода виділення ДНК залежить від устаткування лабораторії, навичок фахівців-експертів, часу, відведеного 
на дослідження біологічного матеріалу, кількості та якості біологічного матеріалу. Основними задачами даного етапу є ефективне видалення парафіну та очистка ДНК від білків (гістонів), жирів, вуглеводів та неорганічних домішок і осадження ДНК.

Основною проблемою дослідження «гістологічних препаратів на скельцях» є насамперед мінімальна кількість біологічного матеріалу, зумовлена тім, що з тканини роблять зріз товщиною до 10 мкм, тобто почат- кова кількість матеріалу знаходиться в межах зрізу, теоретично це близько 1,0 2,0 мг. Далі умови фіксації біологічного матеріалу та іiі спосіб, умови проведення етапу заливки тканини у парафін та методика фарбування. У зв'язку 3 вищевикладеним, актуальним $\epsilon$ систематизація отриманих раніше даних та розробка уніфікованого алгоритму по дослідженню біологічного матеріалу у вигляді гістологічного «вологого» архіву,

«парафінових блоків» та «гістологічних препаратів на скельцях» за допомогою молекулярногенетичних методів для підвищення теоретичного та практичного рівня використання ДНК-аналізу при проведенні судово-медичної експертизи даних об’єктів.

Досвід роботи, який ми отримали в процесі проведення вищеназваної науково-дослідної роботи, досвід вітчизняних та зарубіжних колег, дав змогу виділити напрями роботи і шляхи вирішення основних завдань, про- вести аналіз отриманих результатів та сформулювати відповідні науково-обгрунтовані методологічні положення проведення судово-медичної експертизи речових доказів - гістологічних препаратів.

Мета роботи. Розробка та впровадження в експертну практику алгоритму проведення судовомедичної ек- спертизи речових доказів - об'єктів судово-медичного гістологічного дослідження, а саме: фіксованих біологічних тканин, відібраних від трупів, у вигляді «волого архіву», «парафінових блоків», фіксованих біологічних тка- нин біопсійного матеріалу у вигляді «парафінових блоків» та фарбованих гістологічних препаратів на пред- метних скельцях для підвищення якісного рівня вирішення експертних задач з метою встановлення біологічної спорідненості та ідентифікації особи 3 використанням сучасної методології ДНК-аналізу.

Для досягнення поставленої мети вирішували наступні завдання:

1.Визначали вплив тривалості та температурних умов формалінової фіксації біологічних тканин на якість та кількість виділеної ДНК та можливість ії використання для встановлення ДНК-профілю;

2.Визначали найбільш ефективний спосіб проведення молекулярно-генетичного дослідження фіксованих тканин - об’єктів судово-гістологічного дослідження у вигляді «парафінових блоків» для встановлення ДНК- профілю;

3.Визначали найбільш ефективний спосіб проведення молекулярно-генетичного дослідження фіксованих тканин - об'єктів клінічного гістологічного дослідження у вигляді «парафінових блоків» та аналогічних об'єктів у вигляді фарбованих гістологічних препаратів на предметних скельцях.

4.Розробляли алгоритм проведення судово-медичної експертизи речових доказів - об’єктів судово-медич- ного гістологічного дослідження, а саме фіксованих біологічних тканин відібраних від трупів у вигляді «волого архіву», «парафінових блоків» та фіксованих біологічних тканин біопсійного матеріалу у вигляді «парафінових блоків» та фарбованих гістологічних препаратів на предметних скельцях.

Структура науково-дослідної роботи складалася відповідно до поставлених завдань, які вирішували поетапно та протягом певного часу шляхом дослідження експериментальних об'єктів об’єкти судово-медичного гістологічного і гістологічного дослідження, виготовлені з біологічних тканин трупів та живих осіб.

На першому етапі роботи визначали вплив тривалості та температурних умов формалінової фіксації біологічних тканин - об'єктів судово-медичного гістологічного дослідження, на якісні та кількісні характери- стики виділеної ДНК та можливість ії використання для встановлення ДНКпрофілю $з$ метою вирішення питан- ня про придатність «вологого» архіву в якості біологічних зразків. Показано, що оптимальний термін фіксації біологічних об'єктів в умовах кімнатної температури $\left(22^{\circ} \mathrm{C}\right)$ за допомогою $10 \%$ розчину нейтрального формаліну відповідно до кількісних та якісних характеристик ДНК, виділеної із гістологічних препаратів у вигляді «воло- гого» архіву складає 6 годин, термін фіксації при відповідних обставинах може бути подовжений до 9 годин. Фіксація біологічного матеріалу в умовах побутового холодильника при температурі $4{ }^{\circ} \mathrm{C}$ протягом 12 годин є оптимальною для отримання повного ДНК-профілю, але при відповідних обставинах може бути подовжена до 24 годин. 
Таким чином, на першому етапі роботи при дослідженні експериментального матеріалу та використанні наявного обладнання і реагентів були визначені оптимальні терміни та температурні умови фіксації біологічних тканин - об'єктів судово-медичного гістологічного дослідження. Дані умови не відображаються на стані та характеристиках судово-медичних гістологічних об'єктів.

Внаслідок чого, за рахунок визначених умов і взаємодії судово-медичних експертів-генетиків, судово-медичних експертів загального профілю та судово-медичних експертів-гістологів, які виконують первинні експертизи із застосуванням гістологічних методів, можливим є використовувати «вологий» архів в якості біологічних зразків для дослідження за допомогою молекулярно-генетичних методів з метою встановлення біологічної спорідненості та ідентифікації особи [4].

Більш докладна інформація стосовно проведеної наукової роботи опублікована у Збірнику наукових праць співробітників НМАПО ім. П.Л. Шупика, Випуск № 29, Київ 2018 рік, С. 21-33, «Особливості судово-медичного дослідження геномної ДНК, виділеної з біологічних тканин, фіксованих формаліном».

На другому етапі визначали найбільш ефективний спосіб проведення молекулярно-генетичного дослідження фіксованих тканин - об'єктів судово-гістологічного дослідження у вигляді «парафінових блоків» для встановлення ДНК-профілю. В роботі проведено аналіз загальновідомих способів депарафінізації і декількох методів виділення ДНК.

Показано, що існує залежність між способами депарафінізації біологічних тканин і методами виділення ДНК. Запропонований нами спосіб: видалення парафіну (депарафінізацію) проводили зі шматочків (не зі зрізів) тканини, з використанням фізичного способу, тобто нагріванням в умовах стабілізуючого буферу (протягом 20 хв. в режимі інтенсивного ротаційного перемішування 1000-1200 об/хв. при температурі $\left.70{ }^{\circ} \mathrm{C}\right)$, до складу якого входить 10 мМ Трис-HCl, 10 мМ ЕДТА (pH 8,5 при $25^{\circ} \mathrm{C}$ ). Наявність у розчині Трис-НСl забезпечує буферні властивості розчину до потрібної $\mathrm{pH} 8,5$, що зупиняє активізацію хімічних реакцій окиснення і гідролізу, та дію нуклеаз, а ЕДТА хелатує іони важкихф металів, що запобігає ініціації свободнорадікальних процесів. Також нами запропоновано оптимізувати процес виділення ДНК, ввести двоетапну процедуру, а саме попередній етап виділення ДНК, сутність якого полягає в початковій депротеїнізації та видаленні залишків формаліну, в умовах стабілізуючого буферу з додаванням протеолітичного ферменту протеїнази К, який викликає швидку денатурацію білків й інактивацію нуклеаз. Для підвищення ефективності депротеїнізації (роботи ферменту) до стабілізуючого буферу додавали реагент тіовідновлювач - дітіотрейтол (DTT), який руйнує дисульфідні білкові зв'язки, у кінцевій концентрації до 40 мМ. Основний етап виділення ДНК проводили за допомогою комерційного спеціального набору реагентів «PrepFiler® Forensic DNA Extraction Kit» («Applied Biosystems», CШA).

Таким чином, на другому етапі роботи при дослідженні експериментального матеріалу та використанні наявного обладнання і реагентів нами був запропонований спосіб який дає можливість виділити достатню кількість придатної для типування ДНК за невеликий проміжок часу, що має істотне значення при обмеженні часу дослідження. Внаслідок чого, запропонований нами спосіб є оптимальним для проведення судово-медичного молекулярно-генетичного дослідження [5].

Більш докладна інформація стосовно проведеного етапу наукової роботи опублікована в статті в науковому журналі «Vinnytsia National Pyrogov Memorial Medical University» «Biomedical and Biosocial Anthropology», № 29, 2017 рік, С. 93-100, за темою: «Особливості судово-медичного дослідження геномної ДНК, виділеної 3 біологічних тканин, фіксованих формаліном у вигляді «парафінових блоків».

Третій етап роботи присвячений проведенню молекулярно-генетичного дослідження фіксованих тканин об’єктів клінічного гістологічного дослідження у вигляді «парафінових блоків» та аналогічних об’ єктів у вигляді фарбованих гістологічних препаратів на предметних скельцях.

Матеріал і методи дослідження. У якості об’єктів для експериментального дослідження були протестовані дві групи гістологічних препаратів.

Група А - гістологічні препарати біологічних тканин у вигляді «парафінових блоків», відібрані під час проведення біопсій $(\mathrm{n}=42)$. Дані біологічні матеріали відбиралися у різних спеціалізованих лікувальних уста- новах для проведення гістологічного дослідження в клінічній практиці 3 метою діагностики онкологічних захво- рювань. Матеріал відбирався відповідно від живих осіб чоловічої та жіночої статі, біологічний матеріал фахівці лікувальних установ досліджували відповідно до методики гістологічної експрес фіксації (теплим 10 \% розчином формаліну протягом 15-30 хв.) не пізніше ніж через 15-30 хв. після проведення хірургічних маніпуляцій. Нами матеріал підбирався протягом 20102015 років, інформації стосовно віку осіб та діагнозів представлено не було. Деякий біологічний матеріал ми досліджували відповідно до заяв пацієнтів лікувальних установ у відділенні судовомедичних молекулярно-генетичних експертиз Одеського обласного бюро судово-медичної експертизи з метою встановлення тотожності, внаслідок суперечливих висновків гістологічного дослідження.

Група В - фарбовані гістологічні препарати біологічних тканин на предметних скельцях $(\mathrm{n}=$ 42), об’єктів групи А «парафінових блоків» з яких зробили відповідні зрізи та пофарбували. 
Спосіб депарафінізації запропонований нами раніше (дивись вище): депарафінізацію проводили зі шматочків тканини (експериментальні об'єкти групи А), шляхом нагрівання в умовах стабілізуючого буферу, до складу якого входить 10 мМ Трис-HCl, 10 мМ ЕДТА (pH 8,5 при $\left.25^{\circ} \mathrm{C}\right)$. Об'єкти дослідження - фіксовані тканини у вигляді «парафінових» блоків подрібнювали за допомогою стерильних скальпелів, в середньому маса наважки складала 25,0 мг, які перенесли у мікроцентрифужні пробірки типу «Еппендорф» об'ємом 1,5 мл додали 1,0 мл стабілізуючого буферу (10 мМ Трис-НCl, 10 мМ ЕДТА (рН 8,5 при $\left.25^{\circ} \mathrm{C}\right)$ ) та інкубували на термошейкері «Biosan TS-100» протягом 20 хв. в режимі інтенсивного ротаційного перемішування (1000-1200 об/хв.) при температурі $70{ }^{\circ} \mathrm{C}$. Після інкубації пробірки з вмістом швидко охолоджували в умовах кімнатного холодильнику до $4{ }^{\circ} \mathrm{C}$ протягом двох хвилин. Парафін утворював твердий шар на поверхні, який видаляли за допомогою одноразових пластикових наконечників. Етап депарафінізації проводили двічі. Вміст пробірок центрифугували 14500 об/хв. протягом 1 хв., отриманий осад - шматочки тканин видаляли та просушували за допомогою стерильних серветок.

Далі проводили попередній етап виділення ДНК: висушені шматочки тканин перенесли у мікроцентрифужні пробірки типу «Еппендорф» об'ємом 1,5 мл додали 1,0 мл стабілізуючого буферу (10 мМ Трис-НCl, 10 мМ ЕДТА (рН 8,5 при $\left.25^{\circ} \mathrm{C}\right)$, протеіназу К (20 мг/мл) до кінцевої концентрації 0,1 мг/мл, та дітіотрейтол (1 M) до кінцевої концентрації $40 \mathrm{MM}$ ) та інкубували на термошейкері «Biosan TS-100» протягом 180 хв. в режимі інтенсивного ротаційного перемішування (1000-1200 об/хв.) при температурі $60{ }^{\circ} \mathrm{C}$. Лізат центрифугували при 14500 об/хв. протягом 1 хв., над осадовий розчин зливали. Далі з отриманого осаду процедуру виділення ДНК 3 досліджуваних об’єктів проводили за допомогою комерційного спеціального набору реагентів «PrepFiler® Forensic DNA Extraction Kit» («Applied Biosystems», США) для виділення ДНК з криміналістичних зразків, за відповідним рекомендованим виробником протоколом для дослідження біологічного матеріалу.

3 препаратів групи В (фарбовані гістологічні препарати біологічних тканин на предметних скельцях) механічно видаляли покривні скельця, після чого за допомогою стерильних одноразових скальпелів 3 предметних скелець видаляли зрізи з залишками бальзаму. Фрагменти зрізів перенесли у мікроцентрифужні пробірки типу «Еппендорф» об’ ємом 1,5 мл додали 1,0 мл ксилолу, інкубували на термошейкері «Biosan TS-100» в режимі інтенсивного ротаційного перемішування (1000-1200 об/хв) при температурі $22{ }^{\circ} \mathrm{C}$ протягом 15 хв., центрифугували при 14500 об/хв протягом 1 хв., ксилол видаляли, додавали 1,0 мл етанолу 96 \%, перемішували, центрифугували при 14500 об/хв протягом 1 хв., етанол видаляли, додавали 1,0 мл стабілізуючого буферу (10 мМ Трис-HCl, 10 мМ ЕДТА (рН 8,5 при $25{ }^{\circ} \mathrm{C}$ ), протеіназу К (20 мг/мл) до кінцевої концентрації 0,1 мг/мл, та дітіотрейтол (1M) до кінцевої концентрації $40 \mathrm{MM})$ та інкубували на термошейкері «Biosan TS-100» протягом 20 хв. в режимі інтенсивного ротаційного перемішування (1000-1200 об/хв) при температурі $60{ }^{\circ} \mathrm{C}$. Лізат центрифугували при 14500 об/хв протягом 1 хв., надосадовий розчин зливали. Після проведення попереднього етапу виділення ДНК, процедуру безпосередньої очистки та виділення ДНК з досліджуваних об’єктів проводили за допомогою комерційного спеціального набору реагентів «PrepFiler ${ }^{\circledR}$ Forensic DNA Extraction Kit» («Applied Biosystems», США) .

Концентрацію виділеної геномної ДНК визначали за допомогою флюориметра Qubit 2.0 Instrument Q 32866 («Invitrogen», США) та набору реагентів Qubit® dsDNA BR, виробництва («Invitrogen», США), для кількісного визначення дволанцюгової ДНК, відповідно до інструкції, яка додається виробниками реагентів.

Виділену ДНК фракціонували методом горизонтального «підводного» електрофорезу в електрофорезній камері «Hoefer Scientific Instruments» (США). Електрофорез здійснювали протягом 1 год. при напрузі постійного струму 70 В у 1хТВЕ буфері (50 мМ Трис-Н3ВО3; 2 мМ Na3ЕДТА; рН 8,0) в 1\%-му агарозному гелі $з$ додаванням бромистого етидію до кінцевої концентрації 0,5 мкг/мл. При проведенні електрофорезу одна або кілька доріжок містили маркер молекулярної ваги рGEM® DNA Markers («Promega», США) і контрольну високомолекулярну ДНК («Promega», США) з концентрацією 10 нг/мкл. Виділену ДНК, а також контрольну високомолекулярну ДНК наносили на гель у кількості 10,0 мкл.

Типування гіперваріабельних STR-локусів ДНК геному людини проводили в мультилокусному форматі за допомогою полімеразної ланцюгової реакції (ПЛР), використовували набор реагентів для ПЛР-ампліфікації «AmpFlSTR®Identifiler®Plus» («Applied Biosystems», CША), з використанням систем ензиматичної ампліфікації наступних локусів: локуси D8S1179, D21S11, D7S820, CSF1PO, D3S1358, TH01, D13S317, D16S539, D2S1338, D19S433, vWA, TPOX, D18S51, D5S818, FGA, Amelogenin), відповідно до інструкції, яка додається виробниками реагентів. При постановці ПЛР здійснювали негативний контроль (реакційна суміш містила всі компоненти, крім ДНК) і позитивний контроль (реакційна суміш містила ДНК із відомим набором алелів по кожному локусу). Для оцінки специфічності реакції використовували позитивний контроль (проба контрольної ДНК 9947А, яка входить до складу набору). Дослідження проводили з використанням системи «GeneAmp® PCR 2720» («Applied Biosystems», США).

Розділення та детекцію флюоресцентно мічених ампліфікованих фрагментів проводили з використанням автоматичного аналізатору ДНК «3130 Genetic Analyzer» («Applied Biosystems», США) в середовищі полімеру POР-4, довжина капілярів - 36,0 см, час прогону 45 хв. Визначення довжин ампліфікованих фрагментів та встановлення номерів алелей проводили відповідно до внутрішнього стандарту довжини GeneScan-600 LIZ Size 
Standard («Applied Biosystems», США) та алельного леддеру, який входить до набору, за допомогою програмного комплексу «Gene Mapper ID Software Version 3.1».

Статистичний аналіз результатів дослідження проводили з використанням t-критерію Стьюдента, який визначався за допомогою комп'ютерної програми Statistica - 6. Вірогідною вважили різницю між порівнюваними групами при $\mathrm{P}<0,05$.

РЕЗУЛЬТАТИ ДОСЛІДЖЕННЯ ТА ЇХ ОБГОВОРЕННЯ. Результати проведеної науково-дослідної роботи по проведенню молекулярно-генетичного дослідження фіксованих тканин об'єктів клінічного гістологічного дослідження у вигляді «парафінових блоків» та аналогічних об'єктів у вигляді фарбованих гістологічних препаратів на предметних скельця оцінювали відповідно до наступних критеріїв: кількісні та якісні характеристики виділеної геномної ДНК; придатність виділеної ДНК для аналізу методом ПЛР (можливість отримання продуктів ампліфікації на матриці виділеної ДНК та отримання повного генетичного профілю. Якість (автентичність) ДНК-профілів об’єктів встановлювали шляхом проведення порівняльного аналізу отриманих ДНК-профілів.

I етап. Визначали кількість ДНК (нг), виділеної із біологічних об’єктів групи А та групи В. Дані про кількість виділеної ДНК (нг) показані в таблиці 1

Таблиия 1

Кількість ДНК (нг), виділеної із біологічних об’ сктів групи А і групи В

\begin{tabular}{|c|c|c|c|}
\hline Групи об'єктів дослідження & Середнє значення, М & Мінімальне значення & Максимальне значення \\
\hline Група А $(\mathrm{n}=42)$ & 372,0 & 270,0 & 380,0 \\
\hline Група В $(\mathrm{n}=42)$ & 36,5 & 24,0 & 42,0 \\
\hline
\end{tabular}

Відповідно до даних, наведених у таблиці 1 випливає наступне: дані показують, що існує різниця між кількістю ДНК, виділеної із гістологічних препаратів біологічних тканин у вигляді «парафінових блоків» та пофарбованих гістологічних препаратів біологічних тканин на предметних скельцях, тобто кількість ДНК, отриманої з об'єктів групи А у 10 разів більша відносно об'єктів групи В. Даний факт пояснюється початковою кількістю досліджуваного матеріалу.

В цілому, в умовах проведеного дослідження об’єктів групи А виявилося можливим виділити ДНК в середній кількості 372,0 нг, що показує достатньо високій рівень ефективності запропонованого способу та методу виділення ДНК. При роботі з препаратами групи В кількість виділеної ДНК отримана на достатньо високому рівні, що показує придатність даних препаратів для молекулярно-генетичних досліджень.

Також, необхідно підкреслити, що об’єкти препаратів груп А і В зберігалися у вигляді парафінових блоків та пофарбованих гістологічних препаратів біологічних тканин на предметних скельцях до восьми років, при цьому кількість виділеної ДНК зберігається на достатньо високому рівні.

II етап. Результати електрофоретичного розділення ДНК, виділеної із біологічних об'єктів груп А і В, демонструють, що виділена ДНК — фрагментована та має молекулярну масу в межах від 5000 до 250 п. н., 31 збереженням фракції високомолекулярних фрагментів, при візуалізації фрагментів із меншою масою (від 250 п. н. i вище), що дає змогу в подальшому успішно використовувати ДНК для ампліфікації. Висновок - спостерігається часткова деградація ДНК клітин досліджуваного матеріалу.

Якісні характеристики ДНК препаратів груп А та В, показують, що деградація ДНК клітин ущільнених в парафін спостерігається повільно протягом років. Тобто дослідження гістологічних препаратів у вигляді «парафінових блоків» так і «гістологічних препаратів на скельцях», які виготовлені 3 біологічних тканин, відібраних під час біопсій може бути ефективне при використанні запропонованої методики та наявного обладнання.

III етап. Визначали придатність ДНК, виділеної із біологічних об’єктів груп А та В методом ПЛР за наступними критеріями: отримання повного ДНК-профілю при типуванні 15 гіперваріабельних STR-локусів ДНК геному людини при використанні набору реагентів для ПЛР-ампліфікації «AmpFISTR®Identifiler®Plus» («Applied Biosystems», США), отримання часткового ДНК-профілю при типуванні, враховуючи ефекти «випадіння» алелей або повну відсутність продуктів ПЛР. Дані про придатність виділеної ДНК показані в таблиці 2.

Як видно з даних, наведених у таблиці 2, повний ДНК-профіль при типуванні 15 гіперваріабельних STRлокусів був отриманий для 38 об'єктів групи А, що складає 90 \% від загальної кількості об'єктів. Неповний (частковий) ДНК-профіль, тобто ДНК-профіль за 8 - 10 гіперваріабельними STR-локусами отриманий для 3 об'єктів. Повна відсутність продуктів ампліфікації спостерігалась при типуванні 1 об'єкту.

Повний ДНК-профіль об’єктів групи В, був отриманий для 40 досліджених об’єктів, що складає 95 \% від загальної кількості об'єктів. Неповний ДНК-профіль та повна відсутність продуктів ампліфікації спостерігалась при типуванні 2 об’єктів, відповідно. 
Результати типування ДНК, виділеної із біологічних об’єктів

груп А та В методом ПЛР, у відповідності до досліджених критеріїв та загальної кількості об’єктів

\begin{tabular}{|c|c|c|c|}
\hline & \multicolumn{3}{|c|}{ Кількість, $\mathrm{n}$} \\
\hline Групи об'єктів дослідження & + & \pm & - \\
\hline Група А $(\mathrm{n}=42)$ & 38 об'єктів $90,0 \%$ & 3 об'єкта $7,0 \%$ & 1 об'єкт $3,0 \%$ \\
\hline Група В $(\mathrm{n}=42)$ & 40 об’єктів $95,0 \%$ & 1 об'єкт $2,5 \%$ & 1 об'єкт $2,5 \%$ \\
\hline
\end{tabular}

Примітка 1. «+»- отримання повного ДНК-профілю при типуванні 15 гіперваріабельних STR-локусів; Примітка 2. «士»- отримання неповного ДНК-профілю при типуванні 15 гіперваріабельних STR-локусів; Примітка 3. «-»- повна відсутність продуктів ензиматичної ампліфікації

IV етап. Визначали якість (автентичність) ДНК-профілів досліджених об'єктів шляхом проведення порівняльного аналізу ДНК-профілів об’єктів груп А і В. Аналізуючи одержані дані встановлено, що: всі отримані повні ДНК-профілі об'єктів групи А цілком співпадають з повними ДНК-профілями відповідних об'єктів групи В, тобто було визначено повне співпадіння ДНК-профілів, що вказує на автентичність отриманих ДНК-профілів.

При проведенні порівняльного аналізу отриманих неповних ДНК-профілів об'єктів групи А та відповідних об’ єктів групи В визначена відсутність алелів для гетерозиготних профілів-ефект випадіння (хибної гомозиготності).

ВИСНОВКИ. Таким чином, результати проведеного дослідження показали, що у якості об’єктів, придатних для проведення судово-медичної експертизи з метою встановлення біологічної спорідненості та ідентифікації особи за допомогою молекулярно-генетичних методів, можуть використовуватися гістологічні препарати біологічних тканин у вигляді «парафінових блоків» та пофарбованих гістологічних препаратів біологічних тканин на предметних скельцях, які були відібрані під час біопсій. При цьому дослідження гістологічних препаратів біологічних тканин при використанні запропонованої методики та наявного обладнання ефективне у 95 та $90 \%$ випадків, відповідно.

Проведена науково-дослідна робота є засобом, за допомогою якого ми провели аналіз та систематизацію всього напрацьованого матеріалу. Отримані результати дослідження дозволяють запропонувати низку рекомендацій, а також алгоритм проведення судово-медичної експертизи речових доказів - об'єктів судовомедичного гістологічного дослідження, а саме: фіксованих біологічних тканин, відібраних від трупів у вигляді «волого архіву», «парафінових блоків», фіксованих біологічних тканин біопсійного матеріалу у вигляді «парафінових блоків» та фарбованих гістологічних препаратів на предметних скельцях з використанням молекулярно-генетичних методів.

Алгоритм проведення судово-медичної експертизи:

1. Біологічний матеріал - шматочки органів та тканин, які відбираються під час проведення судовомедичної експертизи трупів, потрібно фіксувати за допомогою 10 \% нейтрального (забуференого) розчину формаліну не пізніше ніж через 15 хвилин після їх відбору, термін фіксації в умовах кімнатної температури (22 0С) не повинен перевищувати 6 годин, максимальний термін фіксації - 9 годин. Фіксація біологічного матеріалу в умовах побутового холодильника при температурі $4{ }^{\circ} \mathrm{C}$ не повинна перевищувати 12 годин. При таких умовах даний біологічний матеріал - «вологий архів» можливо використовувати в якості біологічних зразків для проведення судово-медичної експертизи речових доказів за допомогою молекулярно-генетичних методів 3 метою встановлення біологічної спорідненості та ідентифікації особи;

2. Біологічний матеріал - фіксовані тканини об’єктів судово-гістологічного дослідження у вигляді «парафінових блоків» може бути використаний в якості біологічних зразків для проведення судово-медичної експертизи речових доказів за допомогою молекулярно-генетичних методів 3 метою встановлення біологічної спорідненості та ідентифікації особи. Запропонований нами спосіб депарафінізації та виділення ДНК є оптимальним для про- ведення молекулярно-генетичного дослідження вищеназваних об'єктів.

3. Запропонований нами спосіб проведення молекулярно-генетичного дослідження фіксованих тканин об’єктів клінічного гістологічного дослідження у вигляді «парафінових блоків» та аналогічних об’ єктів у вигляді фарбованих гістологічних препаратів на предметних скельцях є ефективним для встановлення ДНК-профілю вищеназваних об’єктів.

Дані рекомендації відповідають умовам проведення судово-медичного гістологічного дослідження, тоб- то виконуються всі завдання фіксації: припиняється аутоліз та бактеріальна атака, зберігається форма, об’єм та структура тканини, тканини готові до фарбування, при цьому препарати, завдяки запропонованим нами рекомендаціям, можливо використовувати для проведення ДНК-аналізу та отримання ДНК-профілю. 


\section{Література}

1. Орлова ОА, Ланцман IB. Використання гістологічних препаратів при проведенні судово-медичних молекулярно-генетичних експертиз із метою ідентифікації особи i встановлення біологічного батьківства (материнства). В: Сучасні теоретичні та практичні аспекти клінічної медицини. Тези доповідей науково-практичної конференції з міжнародною участю; 2012 Кві 19-20. Одеса; 2012. с. 34.

2. Ланцман IB. Судово-медичне молекулярно-генетичне дослідження мітохондріальної ДНК біопсійного матеріалу у парафінових блоках. В: Молодь - медицині майбутнього. Тези доповідей міжнародної наукової конференції студентів та молодих вчених; 2013 Бер 14-15. Одеса; 2013.

3. Кривда РГ, Ланцман IB. Дослідження геномної ДНК, виділеної із гістологічних препаратів, для проведення судово-медичних молекулярно-генетичних експертиз. Буковинський медичний вісник. 2013;3(67):83-5.

4. Кривда РГ. Особливості судово-медичного дослідження геномної ДНК, виділеної з біологічних тканин, фіксованих формаліном. Збірник наукових праць співробітників НМАПО ім. П.Л. Шупика. 2018;29:2133 .

5. Кривда РГ. Особливості судово-медичного дослідження геномної ДНК, виділеної з біологічних тканин, фіксованих формаліном у вигляді «парафінових блоків». Biomedical and Biosocial Anthropology. 2017;29:93-100.

\section{References:}

1. Orlova OA, Lantsman IV. Vykorystannia histolohichnykh preparativ pry provedenni sudovo-medychnykh molekuliarno-henetychnykh ekspertyz iz metoiu identyfikatsii osoby i vstanovlennia biolohichnoho bat'kivstva (materynstva) [The use of histological drugs in the conduct of forensic molecular genetic examination to identify a person and establish biological paternity (motherhood)]. V: Suchasni teoretychni ta praktychni aspekty klinichnoi medytsyny. Tezy dopovidei naukovo-praktychnoi konferentsii z mizhnarodnoiu uchastiu; 2012 Kvi 19-20. Odesa; 2012. s. 34. (in Ukrainian)

2. Lantsman IV. Sudovo-medychne molekuliarno-henetychne doslidzhennia mitokhondrial'noi DNK biopsiinoho materialu u parafinovykh blokakh [Forensic molecular genetic analysis of mitochondrial DNA of biopsy material in paraffin blocks]. V: Molod' - medytsyni maibutn'oho. Tezy dopovidei mizhnarodnoi naukovoi konferentsii studentiv ta molodykh vchenykh; 2013 Ber 14-15. Odesa; 2013. (in Ukrainian)

3. Kryvda RH, Lantsman IV. Doslidzhennia henomnoi DNK, vydilenoi iz histolohichnykh preparativ, dlia provedennia sudovo-medychnykh molekuliarno-henetychnykh ekspertyz [Investigation of genomic DNA, extracted from histological preparations, for conducting forensic-medical molecular-genetic examinations]. Bukovyns'kyi medychnyi visnyk. 2013;3(67):83-5. (in Ukrainian)

4. Kryvda RH. Osoblyvosti sudovo-medychnoho doslidzhennia henomnoi DNK, vydilenoi z biolohichnykh tkanyn, fiksovanykh formalinom [Features of forensic medicine investigation of genomic DNA extracted from formalinfixed biological tissues]. Zbirnyk naukovykh prats' spivrobitnykiv NMAPO im. P.L. Shupyka. 2018;29:21-33. (in Ukrainian)

5. Kryvda RH. Osoblyvosti sudovo-medychnoho doslidzhennia henomnoi DNK, vydilenoi z biolohichnykh tkanyn, fiksovanykh formalinom u vyhliadi "parafinovykh blokiv" [Features of forensic-medicine investigation of genomic DNA extracted from formalin fixed biological tissues in the form of "paraffin blocks"]. Biomedical and Biosocial Anthropology. 2017;29:93-100. (in Ukrainain)

\section{АЛГОРИТМ ПРОВЕДЕНИЯ СУДЕБНО-МЕДИЦИНСКОЙ ЭКСПЕРТИЗЫ ВЕЩЕСТВЕННЫХ ДОКАЗАТЕЛЬСТВ - БИОЛОГИЧЕСКИХ ТКАНЕЙ, ФИКСИРОВАННЫХ В ФОРМАЛИНЕ, С ПОМОЩЬЮ МОЛЕКУЛЯРНО- ГЕНЕТИЧЕСКИХ МЕТОДОВ \\ Кривда Р. Г., Ланцман И. В.}

Резюме. В работе рассмотрены вопросы проведения судебно-медицинской экспертизы вещественных доказательствобъектов судебно-медицинского гистологического исследования, а именно: фиксированных биологических тканей, отобранных от трупов в виде «влажного архива», «парафиновых блоков» и фиксированных биологических тканей биопсийного материала в виде «парафиновых блоков» и окрашенных гистологических препаратов на предметных стеклах.

Ключевые слова: ПЦР, биологическая ткань, фиксированная формалином в «парафиновых блоках», депарафинизация, геномная ДНК, судебно-медицинская экспертиза.

\section{ALGORITHM OF FORENSIC STUDY OF FORMALIN-FIXED BIOLOGICAL TISSUES USING METHODS OF MOLECULAR GENETICS \\ Krivda R. G., Lantsman I.V.}


Summary. The following investigation is dedicated to forensic study of biological evidences represented by objects of forensic medical histology, namely formalin-fixed biological tissues, taken from corpses in the form of «wet archive» and «paraffin blocks», as well as fixed biological tissues of biopsy material in the form of «paraffin blocks» and stained histologial preparations.

Key words: PCR, biological tissue, formalin-fixed, "paraffin blocks", dewaxing, genomic DNA, forensic study.

УДК: 340.6:[616.127:616.5]-091.1-91.8(043.3)

\title{
ДЕЯКІ АСПЕКТИ МЕТОДИКИ ТА СУДОВО-МЕДИЧНОї ОЦНКИ ДИНАМОМЕТРІї ТРУПНИХ ПЛЯМ
}

\author{
СГуров О.М. ${ }^{1}$, Гладких Д.Б. ${ }^{1}$, Місюра С.Ю. ${ }^{2}$, Сапєлкін В.В.1 \\ Харківська медична академія післядипломної освіти 1 \\ Харківський національний економічний університет імені С.Кузнеця2
}

\begin{abstract}
Анотація. Визначення давності настання смерті (ДНС) залишається актуальною науковою та практичною проблемою у судово-медичній експертизі. Мінливість трупних плям, що досліджується динамометричним методом, є одним із діагностичних критеріїв визначення ДНС у ранньому посмертному періоді. В Україні 370 -х років минулого сторіччя визначення ДНС за результатами динамометрії трупних плям базується на статистично опрацьованих даних докторської дисертації B.I. Кононенка (1971р.). На теперішній час опрацювання наукових даних у галузі медичних досліджень здійснюється за допомогою комп'ютерних програм з використанням сучасних методів математичної статистики, що відповідають принципам доказової медицини. Проведено критичній аналіз роботи В.І. Кононенка та виконано сучасне математико-статистичне опрацювання даних динамометрії, наведених в його дослідженні. Представлена нова діагностична таблиця визначення ДНС за часом відновлення забарвлення трупних плям.

Ключові слова: судово-медична експертиза, давність настання смерті, трупні плями, динамометрія.
\end{abstract}

ВСТУП. Діагностика давності настання смерті (ДНС) в практиці судово-медичного експерта є необхідним завданням, вирішення якого спрямоване на розкриття кримінального злочину. В експертній діяльності для вирішення цього питання використовується широке коло діагностичних критеріїв в залежності від терміну, що минув з моменту настання смерті. У ранньому посмертному періоді досліджуються наступні посмертні процеси [1]:

1. Процеси, притаманні живому організму, що поступово згасають після настання смерті. Такі процеси зумовлюють суправітальні реакції.

2. Процесів, які розвиваються лише після настання смерті, - трупні явища.

До трупних явищ, які спостерігаються у ранньому посмертному періоді, відносять охолодження трупа, висихання трупу, посмертне розм'якшення очних яблук, трупні плями, трупне задубіння, трупний автоліз [2]. Завдяки розвитку судової медицини пріоритети щодо вивчення окремих трупних явищ 3 часом змінювалися. У 1960 році Э. Кноблах [3] відмічав, що при визначенні часу настання смерті температура трупу використовується відносно рідко, частіше висновок про давність настання смерті базується на дослідженні трупних плям та трупного заклякання. В останні десятиріччя пріоритет у визначенні ДНС набули наукові дослідження, присвячені трупному охолодженню $[4,5,6]$. На теперішній час з огляду на діагностичну значущість отриманих наукових результатів трупне охолодження є найбільш вагомим діагностичним критерієм визначення ДНС у ранньому посмертному періоді, кількісне вимірювання якого враховує вплив чинників внутрішнього та навколишнього середовища, а його точність підтверджена багатьма незалежними дослідженнями [7]. Однак, в практиці вітчизняних судово-медичних експертів дослідження трупних плям залишається основним в діагностиці ДНС, хоча в країнах Європейського Союзу означене дослідження застосовується лише як допоміжне.

Однією $з$ широко репрезентованих на теренах радянського та пострадянського простору робіт щодо вивчення трупних плям є дисертаційне дослідження В.І. Кононенка (1971) «Комплекное физико-химическое исследование трупных пятен» [8]. 3 досліджених діагностичних критеріїв найбільшого поширення у судовомедичному середовищі $[2,9,10,11,12,13]$ набули результатами дозованого натискання на трупну пляму - динамометрії. Саме ця методика й відповідна таблиця для оцінки ії результатів (див. табл. 2) найчастіше наводяться у фаховій вітчизняній судово-медичній літературі $[14,15,16,17,18]$.

Дослідженню трупних плям шляхом дозованого натискання на них також присвячена значна кількість наукових робіт інших вчених, зокрема країн СНД [19, 20, 21, 22, 23].

На відміну від вітчизняних джерел у фаховій літературі країн Європи та США [7, $24-31]$ відсутні посилання на дослідження трупних плям шляхом динамометрії. Для встановлення ДНС пропонуються інші діагностичні критерії, які виявляються при дослідженні трупних плям: їх поява; початок злиття; максимальний прояв; зникнення при натисканні пальцем; повне або часткове переміщення трупних плям.

У роботі В.І. Кононенка [8] у главі 1 «Методика и материал исследования» наводиться методика дослідження трупних плям «...При обычной локализации трупных пятен на задней поверхности тела нада вливание /фото $2 /$ осуществлялось в поясничной области на протяжении 3 секунд с силой 2 кг/см2 (наш ко- 